\title{
Progressive pseudorheumatoid dysplasia: a close mimicker of juvenile idiopathic arthritis
}

\author{
Partha Pratim Chakraborty, Sugata Narayan Biswas, Shinjan Patra, Gouranga Santra
}

Department of Medicine Midnapore Medical College \& Hospital, Midnapore, West Bengal, India

\section{Correspondence to} Dr Partha Pratim Chakraborty, docparthapc@yahoo.co.in

Accepted 25 February 2016

\section{DESCRIPTION}

A girl aged $11^{1} \frac{1}{2}$ years was referred to the endocrinology clinic with a provisional diagnosis of short stature secondary to juvenile idiopathic arthritis (JIA). Born of a consanguineous union, she had presented to her primary care physician with progressive stiffness and swelling of small joints of the hands and both ankles for the preceding 4 years. Her postnatal and early childhood periods were uneventful with normal developmental milestones.

She was short (height SD score (SDS) -3.8 and mid-parental height SDS -2.3) with an upper: lower segment ratio of 0.83 , suggestive of short trunk dwarfism. Her breasts were of Tanner stage 3. The interphalangeal joints (both proximal and distal) of her hands (figure 1) and her ankles were swollen but non-tender on palpation. The axial skeleton and rest of the joints of the appendicular skeleton were normal without any deformity (such as kyphoscoliosis, genu valgum/varum, coxa vara) and she had no joint contracture.

Baseline biochemistry including erythrocyte sedimentation rate (ESR), $\mathrm{C}$ reactive protein (CRP), rheumatoid factor and antinuclear factor, was normal. Thyroid function tests and insulin-like growth factor 1 (IGF-1) were within reference range. Radiographs of the hands showed large epiphyses, and widened metaphyses of the metacarpals and phalanges, without erosive lesions (figure 2). Bone age was consistent with the chronological age. Beaking of the anterior vertebral bodies and platyspondyly with narrowing of intervertebral disc spaces were observed in X-ray of the spine (figure 3).

Progressive pseudorheumatoid dysplasia (PPD), a distinctive form of spondyloepiphyseal dysplasia (SED) is transmitted in an autosomal recessive manner and characterised by predominant

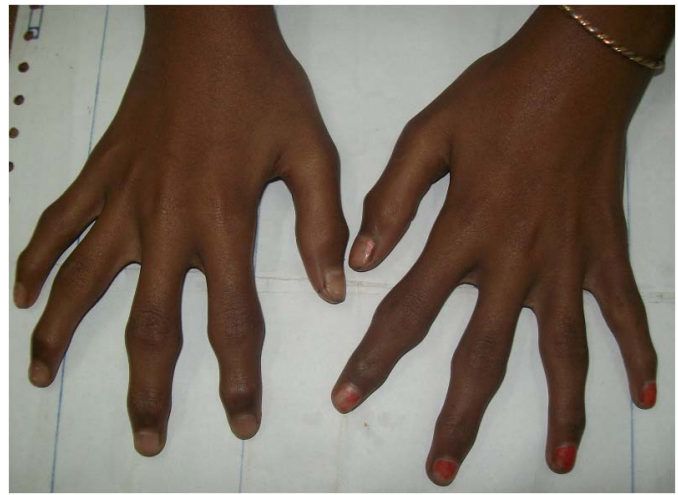

Figure 1 Swollen proximal and distal interphalangeal joints of both hands.

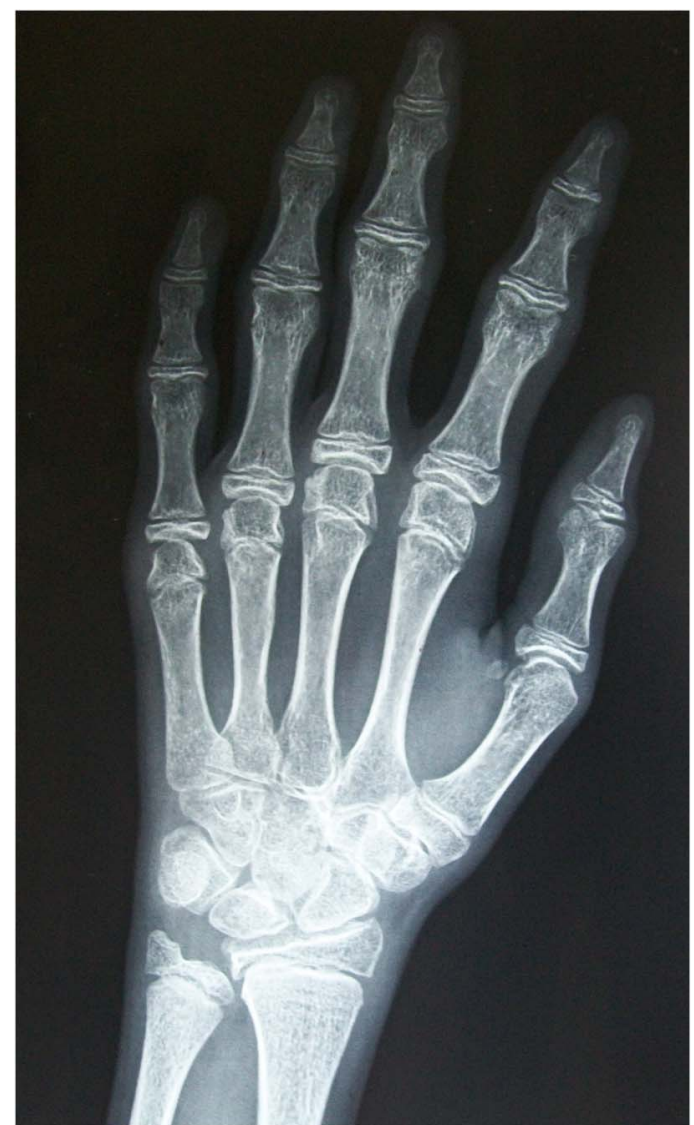

Figure 2 Radiograph of the hand showing large epiphyses, and widened metaphyses of the metacarpals and phalanges without erosions.

involvement of articular cartilages. ${ }^{1}$ This disease is caused by mutations in the WNT1-inducible signalling pathway protein 3 (WISP 3) gene, which is essential for normal growth and functions of joint cartilages. The prevalence of PPD is estimated to be around one per million; however, many cases perhaps are misdiagnosed as JIA. ${ }^{2}$ In absence of a definitive diagnostic criterion, PPD is suspected in individuals with suggestive clinical and radiological findings. This disorder is manifested initially with progressive joint stiffness and enlargement in absence of clinical signs and biochemical markers of inflammation. With onset in early childhood, it gradually involves most of the joints of the extremities and also the spine, resulting in significant morbidity. Stiffness and deformity of the knees, hips and spine, and resultant gait abnormalities, are not uncommon in the late stage of the disease. The characteristic radiological findings in PPD are enlarged epiphyses, widened metaphyses, generalised osteoporosis and platyspondyly. ${ }^{3}$ JIA is perhaps 


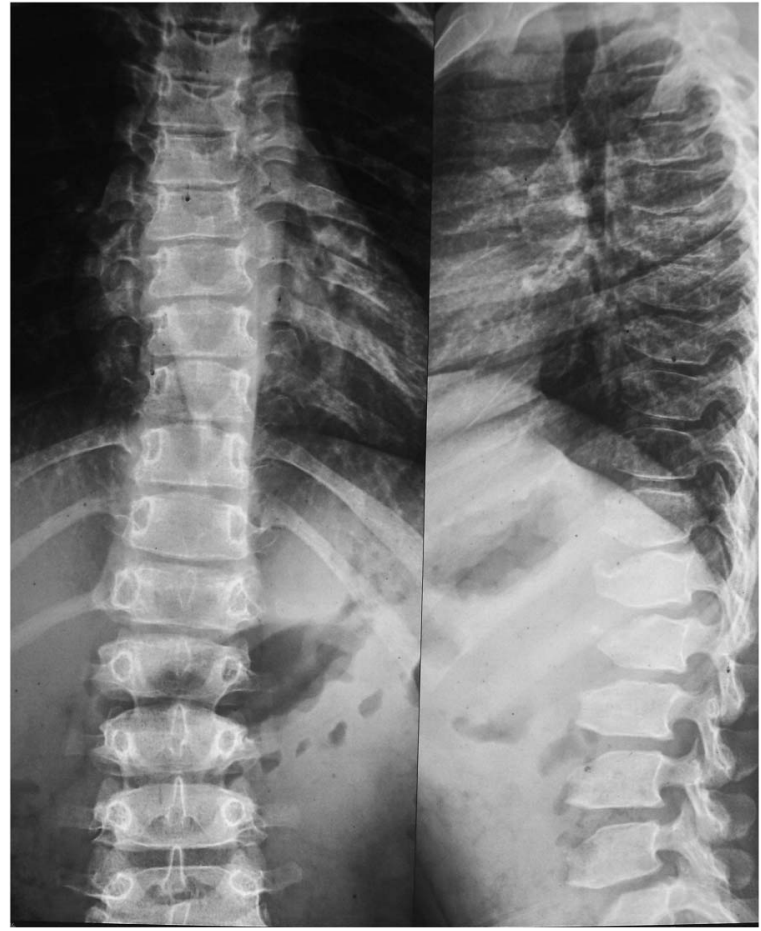

Figure 3 Anterior beaking of the vertebral bodies and platyspondyly on X-ray of the spine.

the most common disorder clinically confused with PPD, particularly in the early stages of the disease. These two diseases can be differentiated by presence of joint inflammation, joint destruction and elevated ESR and CRP in JIA. Moreover, dysplastic vertebrae are not a feature of JIA. Treatment of PPD is supportive with NSAIDs to reduce pain and physical therapy to preserve joint mobility. Immobilisation (eg, casting) should be avoided and advanced cases require intervention by skilled orthopaedists.

\section{Learning points}

- Progressive pseudorheumatoid dysplasia (PPD), though a rare disease, should be kept in mind in the differential diagnosis of juvenile idiopathic arthritis, to prevent delayed diagnosis and to begin early rehabilitation thus avoiding potentially serious late morbidity.

- The combination of non-inflammatory joint disease and radiological abnormalities of the spine is the clue to the diagnosis of underlying PPD.

- A complete radiological survey is a cost-effective and helpful tool in evaluation of short stature without obvious skeletal deformities and normal hormonal studies.

Contributors PPC, SNB, SP and GS were involved in patient management. PPC, SNB and SP were involved in the literature search. PPC wrote the manuscript, and SNB, SP and GS checked and finalised the manuscript.

Competing interests None declared.

Patient consent Obtained.

Provenance and peer review Not commissioned; externally peer reviewed.

\section{REFERENCES}

1 Dalal A, Bhavani G SL, Togarrati PP, et al. Analysis of the WISP3 gene in Indian families with progressive pseudorheumatoid dysplasia. Am J Med Genet A 2012;158A:2820-8.

2 Wynne-Davies R, Hall C, Ansell BM. Spondylo-epiphysial dysplasia tarda with progressive arthropathy. A "new" disorder of autosomal recessive inheritance. J Bone Joint Surg Br 1982;64:442-5.

3 Ehl S, Uhl M, Berner R, et al. Clinical, radiographic, and genetic diagnosis of progressive pseudorheumatoid dysplasia in a patient with severe polyarthropathy. Rheumatol Int 2004;24:53-6.

Copyright 2016 BMJ Publishing Group. All rights reserved. For permission to reuse any of this content visit http://group.bmj.com/group/rights-licensing/permissions.

BMJ Case Report Fellows may re-use this article for personal use and teaching without any further permission.

Become a Fellow of BMJ Case Reports today and you can:

- Submit as many cases as you like

- Enjoy fast sympathetic peer review and rapid publication of accepted articles

- Access all the published articles

- Re-use any of the published material for personal use and teaching without further permission

For information on Institutional Fellowships contact consortiasales@bmjgroup.com

Visit casereports.bmj.com for more articles like this and to become a Fellow 